Article

\title{
Assessing the Ecological Water Level: The Case of Four Mediterranean Lakes
}

\author{
Olga Petriki ${ }^{1, *}$, Dimitrios Zervas ${ }^{2}\left(\mathbb{D}\right.$, Charalampos Doulgeris $^{3}(\mathbb{D})$ and Dimitra Bobori ${ }^{4}(\mathbb{D}$ \\ 1 Institute of Marine Biological Resources and Inland Waters (IMBRIW), \\ Hellenic Centre for Marine Research (HCMR), Elliniko, 16604 Argyroupoli, Attiki, Greece \\ 2 The Goulandris Natural History Museum, Greek Biotope/Wetland Centre, 14th km Thessaloniki-Mihaniona, \\ 57001 Thermi, Greece; dgzervas@gmail.com \\ 3 Soil and Water Resources Institute, Hellenic Agricultural Organization-DG Research, 57400 Sindos, Greece; \\ chdoulgeris@gmail.com \\ 4 Laboratory of Ichthyology, Department of Zoology, School of Biology, Aristotle University of Thessaloniki, \\ 54124 Thessaloniki, Greece; bobori@bio.auth.gr \\ * Correspondence: opetriki@hcmr.gr
}

Received: 24 September 2020; Accepted: 19 October 2020; Published: 23 October 2020

\begin{abstract}
The ecological water regime in lake water bodies refers to the water levels that enable the fulfillment of the ecosystem's multiple functions. Therefore, assessing the ecological water regime necessitates the consideration of hydrological, economic, social, and ecological factors. The present research is focused on the assessment of the ecological water level of four Mediterranean natural lake ecosystems, considering their morphological and biological features. Initially, suggestions on the ecological water regime of the studied lakes were made based on an analysis of the lakes' morphometry. Further, the ecological and biological requirements of the present fish fauna and aquatic macrophytic vegetation were considered. For the latter, mapping was conducted by extensive sampling according to international standards, in order to assess macrophyte composition, abundance, and chorology, as well as species sensitivity to water level fluctuations. The above guided the proposals on the optimal water level regime that should be met by each lake regarding the macrophytic and fish communities' sustainability, also taking into account the unique hydromorphological features of each lake. The differences in the outcoming results revealed that hydromorphological and biological approaches should be combined for assessing lakes' ecological water regimes.
\end{abstract}

Keywords: hydromorphological analysis; macrophytes; fish; sensitive taxa; traits; Greece

\section{Introduction}

Lake water levels in the Mediterranean region vary seasonally, due to the clear presence of two hydroperiods i.e., wet (winter) and dry (summer). During the wet period, the highest rate of precipitation is recorded, while during summer, intense evaporation takes place [1]. Therefore, with a lack of anthropogenic disturbance, the highest water level is normally recorded at the end of the wet season (early spring) and the minimum at the end of the dry season (early fall) [2]. However, this water level pattern may be disturbed due to human activities, which are conducted in the lake catchment, related to urban development and growth of rural areas such as pumping water for irrigation or power generation, flood prevention measurements, diverting streams, and several other hydrological changes [3]. Specifically, human interventions can alter the natural intra-annual and inter-annual amplitude of water level fluctuations as well as the seasonal hydroperiod pattern [2,4], resulting in severe impacts on aquatic ecosystems' functioning and consecutively affecting the biota they support [2]. 
Although the imposed pressures on lake ecosystems, owed to changes in their hydrological regimes, have been acknowledged worldwide [2,5], research on their ecological impacts falls short of research conducted for other anthropogenic disturbances, such as eutrophication increase [6]. Furthermore, limited information exists regarding the ways to recognize the alarm point/level beyond which further amplitude changes should warn concern regarding the undertaking of restoration measures. The above limitations are added to the severe difficulties stakeholders have to deal with when making decisions in the face of trade-offs and conflicts of interest that arise from different ecological, social, economic, and environmental needs in order to manage ecosystem functioning.

"Ecological/environmental water requirements" refer to the water amount required at certain timings for maintaining the ecosystem's diversity and its ecological characteristics, i.e., habitat conservation, biodiversity protection, preservation of human activities, improvement of environmental quality, and maintenance of ecosystem functioning [7]. For lake ecosystems, the ecological water requirements can be easily described using the surface water level. Instead, water flow is used for river systems, thus the counterpart term for describing their water ecological requirements is "ecological flow" [8].

The first attempts for assessing water ecological requirements of aquatic ecosystems were based on historical records (i.e., water level records of past decades) and the morphological features of water bodies. The latter constitute important elements in determining the ecological water regimes of lake ecosystems, which in turn, control water depth and surface area. Specifically, lake morphology is described adequately, in most cases, by the lake level area-volume relationship [9-11]. Lake surface area has also been used as an indicator of climate changes [12] quantifying lake size fluctuations, which in turn may be reflected in habitat protection, assuming that biodiversity increases with the increase in lake surface area [13]. On the other hand, a lake's water volume can be utilized for estimating the amount of water that could be available to fulfill the requirements of economic activities, such as industry, agriculture, etc. Based on the above, the lake surface area method has been proposed by [14] to define the minimum ecological lake level i.e., the level below which there should be no human activities further decreasing the lake's level. Maintaining this level can provide a certain safeguard regarding both lake ecosystems' protection and the fulfillment of anthropogenic needs. The method is principally based on the assumption that lake surface area increases with lake volume, but the rate of increase or the slope of the surface area-volume (S-V) relationship may increase or decrease with the volume, depending on lake morphology that can vary considerably, from large/deep lakes with steep banks to small/shallow ones with mild slopes at the bottom. Thus, a critical lake storage at which the lake surface area does not change significantly may exist. The critical storage corresponding to the breakpoint of the lake surface area-volume curve can be used to define the minimum water level in lakes, similarly to the wetted perimeter method for determining the minimum environmental flow in rivers [15].

Despite the fact that hydromorphological approaches are quite straightforward and easily applicable, they do not implement any biological information, which weakens the ecological perspective for conservation and management issues $[8,16]$. Most recent efforts are characterized by a more holistic approach, aiming at the protection of water's quality, wildlife, and in general, the sustainability of ecosystem operations [7]. This requires cooperation among scientists of different fields, which is generally of great importance for water resources management. For this framework, experts on aquatic biological communities should play a critical role, as the fulfilling of biota's ecological requirements could be an important pillar in the assessment of the ecological water level [7] (Figure 1).

Changes in lake water regime may affect the whole ecosystem's functioning, imposing (directly and/or indirectly) changes in nutrient concentrations, water quality, habitats, and consequently, the biological communities [2]. The severity of the resulting effects upon the last depends on the size of the changes, their duration, and the time they occur $[3,17]$, as well as on the ecological requirements of the organisms and their physiological constitution [2]. However, predicting and quantifying the responses of biological communities to changes in the water regime is rather difficult, posing a major 
constraint to the management of water bodies [18,19]. This is partially a consequence of the fact that changes in biological communities may be a synergistic result of several interrelated causal mechanisms, posing high uncertainty in determining the attributes responsible for altering the water regime $[18,20]$. Among the ecosystem biological components considered, it is widely acknowledged that diversity, abundance, and distribution of both macrophytes and fish are mostly affected by changes in the water regime in lake ecosystems [21-23].

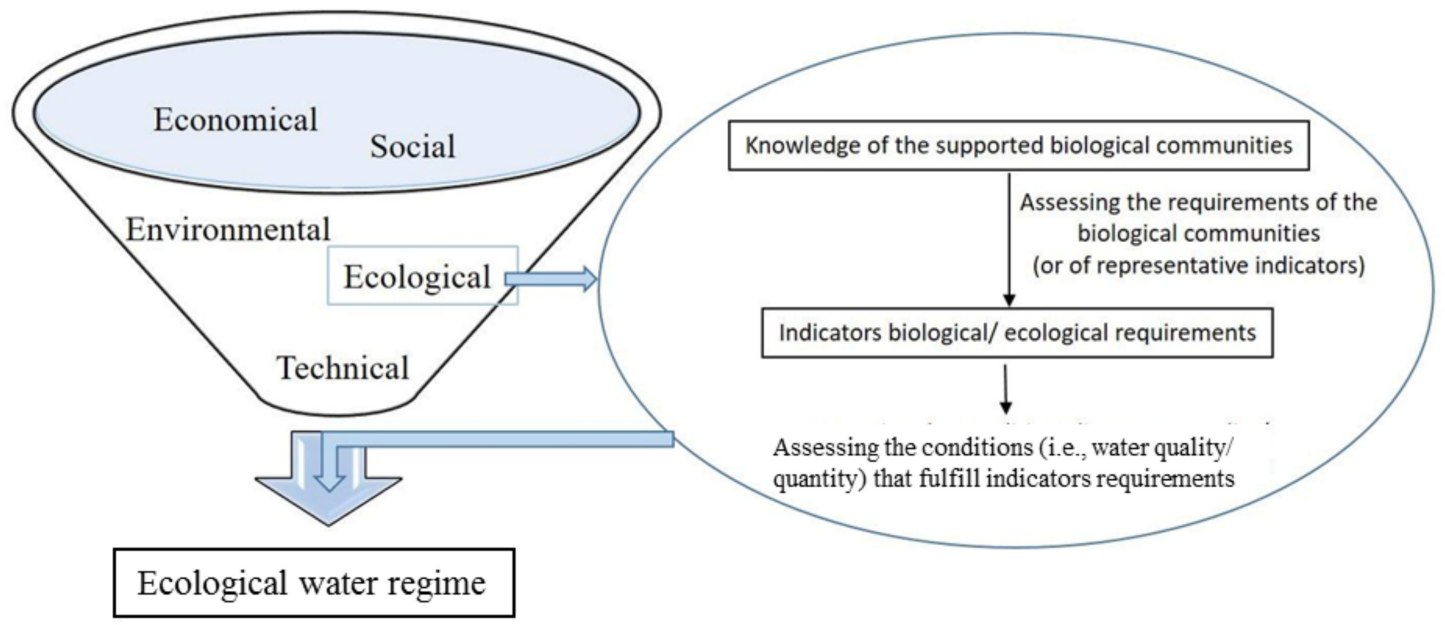

Figure 1. Simplified schematic view of the factors the trade-offs among which should be considered in assessing the ecological water regime of aquatic ecosystems.

Aquatic macrophytes have evolved from terrestrial plants by developing adaptations that help them survive in permanent or seasonally semi-permanent waters, enabling them to colonize the littoral areas of aquatic ecosystems [24,25]. These littoral areas are often extreme habitats, under continuous changes, where only the fittest can survive [26]. For example, under low slope morphology, even small variations in the water level can lead to flooding or drying of large areas, causing a great amount of pressure on sensitive species [17]. Therefore, water regime conditions and/or interspecies competitiveness are important drivers of aquatic macrophyte colonization and succession in littoral communities, which lead to the formation of distinct vegetation zones along the depth gradient $[27,28]$. Lower water level fluctuations favor the establishment of high biomass dominant plant species (e.g., Phragmites australis), leading to vegetation zones with low diversity, while higher water level fluctuations can lower the biomass of dominant species and make space for smaller and less frequent plant species, leading to higher biodiversity [29]. However, if changes in water level fluctuations surpass the tolerance limits of the established macrophytic vegetation in these zones, aquatic plant diversity may drop rapidly [30,31].

The main impacts of water level fluctuations on fish communities result from the impairments posed on the littoral zone, which hosts important reproductive and feeding fields as well as suitable shelters for fish $[3,21,23]$. The above are reflected in fish behavior, distribution, abundance, and growth $[3,23,32]$. For example, the water level regime that enables the presence of dense aquatic vegetation in the littoral zone favors the reproduction of phytophilic species, which prefer to deposit their eggs on plants (i.e., Abramis brama (Linnaeus, 1758), Esox lucius Linnaeus, 1758, Perca fluviatilis Linnaeus, 1758) $[33,34]$. Other species, which also require plants as suitable substrate for their reproduction, such as Rutilus rutilus (Linnaeus, 1758) and Cyprinus carpio (Linnaeus, 1758), may also be favored by the rise in water level that floods terrestrial grassland, providing thus additional reproductive and nesting grounds [35]. On the contrary, a decrease in water level may depress the littoral zone extremely and restrict the number of biota as fish, which use the specific habitats for nourishing, reproduction, and protection. Therefore, the knowledge of fish's biological and ecological preferences (reproductive 
behavior, requirements for reproductive substrate, etc.) is obligatory for assessing the ecological water level of lakes.

The present study targets the assessment of the optimal water level fluctuation in four lakes that could ensure the protection and sustainability of their biological communities by applying an analysis of hydromorphological features and expert judgment based on the ecological requirements of macrophyte and fish species. The proposed ecological minimum water level is further discussed upon the imposed changes in lake surface area and stored water volume.

\section{Study Area}

We studied four lakes (Zazari, Chimaditida, Petron, and Vegoritida), located in Northern Greece (Figure 2, Table 1). The lakes have a catchment area of $2145 \mathrm{~km}^{2}$ and are connected through a hydrographic network. Lake Zazari overflows into Lake Chimaditida above the altitude of 599.7 m.a.s.l., through a canal controlled by a weir. Similarly, the excessive water of Lake Chimaditida overflows above 592.0 m.a.s.l. into a drainage canal, which is joined downstream with a natural stream and ends up at Lake Petron. Finally, Lake Petron overflows above 573.1 m.a.s.l. through an artificial tunnel into Lake Vegoritida (Figure 2).

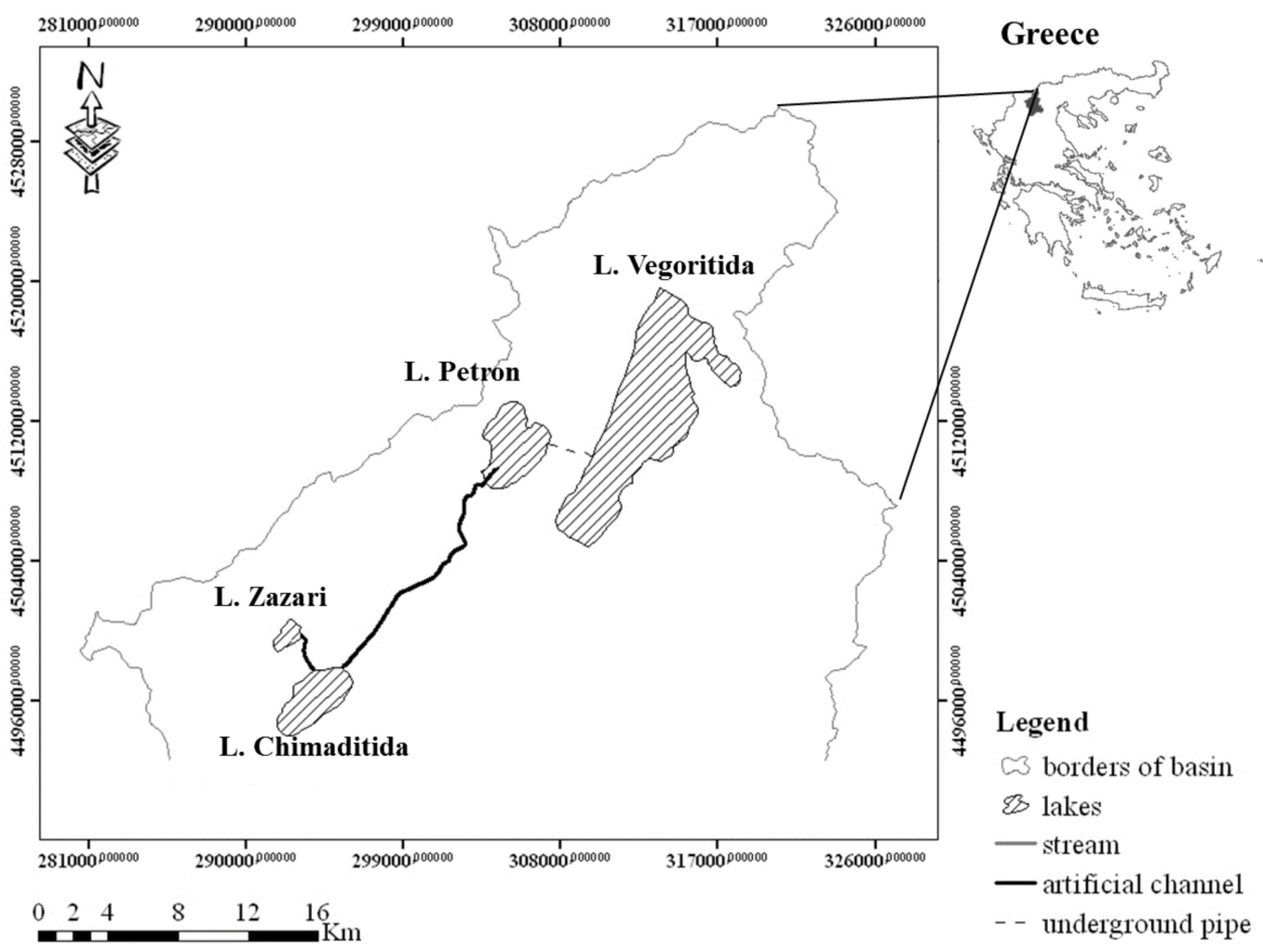

Figure 2. Map of the four studied lakes (Zazari, Chimaditida, Petron, and Vegoritida).

The economic activities in the catchment, imposing pressures on their ecosystems, are mainly related to urbanization, industry development (several steam-electric power plants exploit the lignite deposits in the region, consuming water and augmenting the pollution load), and agriculture. Lake Vegoritida has undergone great water level changes in recent decades (from 542 in 1956 to 525 in the 1980s to 510 m.a.s.l. in 2000: [36]) as a result of water abstraction by the Public Power Corporation. Consequently, the lake has lost $45 \%$ of its volume and $29 \%$ of its surface area. However, the water abstraction ceased and nowadays, the water level is above 517 m.a.s.l (Figure 3).

The water level fluctuation in the four lakes for the period 2012-2015 is shown in Figure 3 (data provided by the Greek Biotope/Wetland Centre, EKBY). The maximum water level is observed 
between February and April and the minimum in September-October. The water level varies annually about $1 \mathrm{~m}$ in Lake Zazari and $0.6 \mathrm{~m}$ in lakes Chimaditida and Petron. In Lake Vegoritida, the water level rises for the aforementioned period but an annual variation can be recognized from 0.6 to $1 \mathrm{~m}$.

Table 1. Hydromorphological characteristics of the four studied lakes. EU—eutrophic; ME—mesotrophic.

\begin{tabular}{ccccc}
\hline Hydromorphological Characteristics & Zazari & Chimaditida & Petron & Vegoritida \\
\hline Max water level $\left(\mathrm{m} \mathrm{a.s.l.}^{2}\right.$ & $599.7^{*}$ & $592.0^{*}$ & $573.1^{*}$ & 518.0 \\
Surface area $\left(\mathrm{km}^{2}\right)$ & 2.0 & 10.1 & 12.6 & 47.2 \\
Stored volume $\left(10^{6} \mathrm{~m}^{3}\right)$ & 9.7 & 14.7 & 40.8 & 1206.2 \\
Mean depth $(\mathrm{m})$ & 5.0 & 1.5 & 3.5 & 26.0 \\
Maximum depth $(\mathrm{m})$ & 7.6 & 4.8 & 5.5 & 52.6 \\
Trophic level & EU & EU & EU & ME-EU \\
\hline
\end{tabular}

* overflow level.
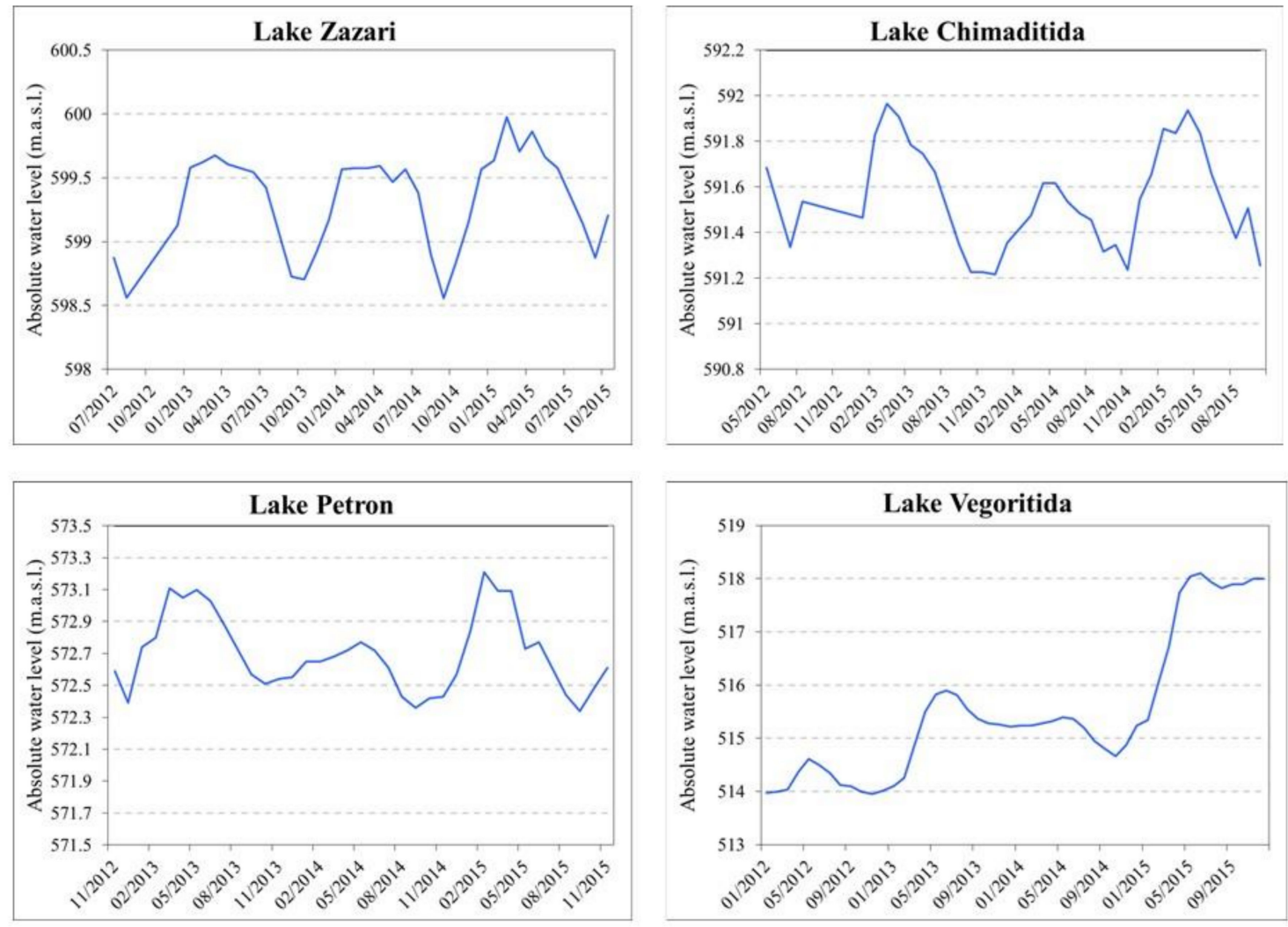

Figure 3. Water level fluctuations in lakes Zazari, Chimaditida, Petron, and Vegoritida for the period 2012-2015 (data provided by the Greek Biotope/Wetland Centre, EKBY).

\section{Materials and Methods}

\subsection{Assessing the Maximum Ecological Water Level}

Setting a maximum water level was necessary in order to discuss the acceptable amplitude of the water level fluctuations during a year and consequently, to make suggestions regarding the minimum ecological water level. Therefore, for lakes Zazari, Chimaditida, and Petron the maximum water level was set at their overflow level (599.7, 592, and 573.1 m.a.s.1., respectively). Considering the water level fluctuations in Lake Vegoritida over recent decades, its water regime pattern is considered highly unstable. However, the higher water level records in recent years (Figure 3) were very promising, considering the eutrophication problems the lake faces. Based on the above and taking into 
consideration the water level fluctuations in recent years, the maximum water level for Lake Vegoritida was set at 518 m.a.s.l. (Table 1).

\subsection{Hydromorphological Analysis}

The bathymetric Digital Elevation Model (Greek Biotope/Wetland Centre, http://nmwn.ypeka. gr/en) of each lake was used to extract a high accuracy water level-surface area curve and a water level-volume curve [37] (Appendix A, Figure A1). Based on the morphological features as expressed by these two curves, the minimum water level for each lake was calculated from the multi-objective optimization model $[14,38]$ :

$$
\begin{gathered}
\max \mathrm{z}_{1}=\mathrm{s}(\mathrm{v})=\mathrm{S}(\mathrm{V}) / \mathrm{V}_{\max } \\
\min \mathrm{z}_{2}=\mathrm{v}=\mathrm{V} / \mathrm{V}_{\max }
\end{gathered}
$$

where $\mathrm{z}$ is the water level, and $\mathrm{s}$ and $\mathrm{v}$ are the dimensionless lake surface area and volume, respectively. The first equation (Equation (1)) represents the maximization of lake surface area, taking into account that biodiversity is favored as the lake surface area increases. The second one (Equation (2)) represents the minimization of lake storage in order to meet the water requirements of economic activities to the greatest possible extent. The solution of the optimization problem results in:

$$
\min \left\{\mathrm{w}_{1} \mathrm{v}+\mathrm{w}_{2}[1-\mathrm{s}(\mathrm{v})]\right\}
$$

where $\mathrm{w}_{1}$ and $\mathrm{w}_{2}$ are non-negative weights. Weight $\mathrm{w}_{1}$ expresses the minimization of lake volume to meet water requirements and $\mathrm{w}_{2}$ expresses the maximization of lake surface area to protect as much as possible the habitats in the lake ecosystem. If the weights have the same value, i.e., $\mathrm{w}_{1}=\mathrm{w}_{2}=50 \%$, the two objectives of the optimization model are expressed equally. Three scenarios were tested (by varying the weighted factors $\mathrm{w}_{1}$ and $\mathrm{w}_{2}$ ) to assess the minimum water level the: envScenario $\left(\mathrm{w}_{1}=30 \%, \mathrm{w}_{2}=70 \%\right)$, eqScenario $\left(\mathrm{w}_{1}=\mathrm{w}_{2}=50 \%\right)$, and wuScenario $\left(\mathrm{w}_{1}=70 \%, \mathrm{w}_{2}=30 \%\right)$.

\subsection{Macrophytes}

Macrophyte monitoring was conducted in all studied lakes in 2016 (June-July) according to the belt transect mapping method [39-42]. The number and location of transects were selected by the Jensen method (1977) [43], bathymetric data, habitat maps, and land use maps for the lakes and their catchment areas. Four different groups of riparian habitat types were distinguished around each lake, using the classification scheme of XP T90-328 (2010) Standard. At least three transects were established in each group (this number was higher in cases of high variability e.g., ecological, morphological, and hydrological differences). Specifically, 20 transects were set in Lake Vegoritida, 16 in lakes Petron and Chimaditida, and 12 in Lake Zazari. Transects were perpendicular to the lake shoreline and represented a strip area (of $5 \mathrm{~m}$ width) extended from the shoreline to the maximum depth of plant growth. Sampling was conducted in five depth zones: $0-1,1-2,2-4,4-8$, and $>8 \mathrm{~m}$ [41,44] by means of a double-headed rake with a scaled handle or attached to a rope, a bathyscope, and a geobathymetric device. In each depth zone, five plots, evenly distributed along the increasing depth gradient, were sampled. All angiosperms (helophytes, hydrophytes, amphiphytes, and aquatic forms of land species), pteridophytes, bryophytes, charophytes, and other green filamentous macroalgae (e.g., Cladophora spp.) were recorded in each plot and their abundance was estimated by using the semi-quantitative five-point DAFOR (Dominant, Abundant, Frequent, Occasional, Rare) scale [41,45]. The taxa were determined at the species level by using suitable floras and identification keys [24,46-61].

Based on the vegetation sampling data, a detailed literature search for ecological and physiological studies regarding the recorded macrophytic taxa was conducted (Appendix A, Table A1). The information collected was necessary in order to reveal recorded species' ecological and biological requirements and assist the selection of indicator species, i.e., species whose survival and reproductive abilities are sensitive to hydrological alterations during at least one stage of their biological cycle. 
A combination of the collected scientific information about the ecophysiological requirements of the recorded taxa, along with expert judgment (based on our acquired experience about the survivability of those macrophytic communities in various lakes with different water regimes across the country), led to decisions about the optimal water depth for each indicator species, depicted by habitat suitability curves. Finally, information about the optimal water depth for each indicator species and the chorology of their rooted macrophytic communities, as recorded during sampling efforts in the studied lakes, led to the final decisions on the minimum water level for each lake regarding the sustainability of the macrophytic vegetation communities and the habitats they form.

\subsection{Fish}

Data regarding the fish community composition in the studied lakes and species biology and ecology were derived from the published and "gray" (diploma, master, and doctorate theses, technical reports) literature and Fishbase [62]. Species not confirmed in the lakes in recent decades were considered as disappeared. Precisely, we gathered information regarding the species spawning period and their preferences upon substrate, their diet, and habitat preferences. Thus, all species were categorized in functional reproductive, habitat, and trophic groups. Consequently, as for their preferences upon the reproductive substrate, fish were categorized as lithophilic (preferring gravels), phytolithophilic (preferring plants and gravels), phytophilic (preferring plants), pelagophilic (preferring water column for scattering their eggs), ostracophilic (preferring bivalves for depositing their eggs), psammophilic (preferring gravels and fine material as breeding substrate), and ovoviviparous (hatch eggs within female's body). According to habitat selection, species were distinguished into benthopelagic, which use the whole water column, and benthic that prefer habitats near the substrate. Finally, regarding the diet preferences of adults, fish species were classified into five categories as omnivores, invertivores, planktivores, herbivores, and piscivores. The above categorization aimed at the identification of the feeding, reproductive, and refuge fields of the fish species whose protection is of vital importance for their survival. Moreover, the above information aimed at the selection of indicator species whose monitoring could help in the early detection of water level fluctuation impacts on fish communities. Effort was provided in order for the selected indicator species to represent almost all life history traits. Moreover, species economic importance and their abundance were among the selection criteria used to aid species monitoring.

\subsection{Ecological Water Level Assessment}

The results of the morphological analysis, the water depth preferences of the indicator macrophytes, in relation to their distribution and abundance along the depth gradient, and the need for protection of those vital for fish fauna reproduction, feeding and refuge fields, which were revealed by examining the biological and ecological requirements of fish species, guided the suggestions on the assessment of the ecological water regime for each lake. More specifically, suggestions for each one of the four studied lakes were made on the minimum water level for the wet and dry periods separately and/or the water level amplitudes, in order to enable the enhancement of macrophytic diversity, and protect the reproductive and nursery fields of the fish species, ensuring their sustainability. As those highly important fields are located mainly in the littoral zone of the lakes, the results of the three examined hydrological scenarios regarding the suppression of each lake area and consequently, of the littoral zone were highly considered for suggesting the ecological water regime based on fish.

\section{Results and Discussion}

\subsection{Morphological Analysis}

The three scenarios examined in the analysis of morphological features result in the estimation of minimum water level for the four lakes (Table 2). The environmental scenario (envScenario) favors the lake's biodiversity as it puts the goal to sustain the lake surface area as a higher priority. 
On the other hand, the water use scenario (wuScenario) targets meeting the water requirements of anthropogenic/economic activities in the catchment as it puts the need to use the available water stored in the lake's volume as a higher priority. The equal scenario (eqScenario) lies among these two scenarios and tries to compromise the conflict arising from the two objectives by setting the same value for the two weighted factors, i.e., $\mathrm{w}_{1}=\mathrm{w}_{2}=50 \%$.

The assessed minimum water levels (Table 2 ) depend strongly on the weighted factors $\mathrm{w}_{1}$ and $\mathrm{w}_{2}$. In Lake Zazari, the minimum water level was $3.7 \mathrm{~m}$ below the maximum level (see Table 1) for the envScenario, resulting in a decrease in the lake's surface area by $26 \%$ and water volume by $66 \%$. In the case of eqScenario, the minimum level was $4.8 \mathrm{~m}$ below the maximum level, resulting in a decrease in the lake's surface area and water volume by $37 \%$ and $82 \%$, respectively. In Lake Chimaditida, the minimum water level was assessed $0.7 \mathrm{~m}$ below the maximum level for the envScenario, ensuing $17 \%$ reduction in the surface area of the lake and $46 \%$ in its water volume. The eqScenario that also applied for the same lake resulted in a minimum water level similar to the minimum level extracted from envScenario. The minimum water level estimated in Lake Petron was $2 \mathrm{~m}$ below the maximum for the envScenario and $2.8 \mathrm{~m}$ according to the eqScenario, resulting in a decrease in the lake's surface area by $18 \%$ and $31 \%$, respectively, and by $56 \%$ and $75 \%$, respectively, in the lake's water volume. Finally, in Lake Vegoritida for the envScenario $\left(\mathrm{w}_{1}=30 \%, \mathrm{w}_{2}=70 \%\right)$, the minimum water level was estimated at $1.8 \mathrm{~m}$ below the maximum level, thus leading to a $3 \%$ reduction in the lake's surface area and $7 \%$ of its water volume. In the eqScenario $\left(\mathrm{w}_{1}=\mathrm{w}_{2}=50 \%\right)$ and wuScenario $\left(\mathrm{w}_{1}=70 \%, \mathrm{w}_{2}=30 \%\right)$, the minimum water levels for Lake Vegoritida were assessed around 27 and $40 \mathrm{~m}$ below the maximum level, respectively. These, non-realistic, minimum water levels correspond to a decrease in the lake's surface area by $51 \%$ and $77 \%$, respectively, compared to its maximum surface area. Furthermore, according to eqScenario, the lake's water volume is expected to be decreased by 933.4 million $\mathrm{m}^{3}$ (i.e., $77 \%$ decrease compared to its maximum water volume). Accordingly, the minimum water level estimated by the wuScenario $\left(\mathrm{w}_{1}=70 \%, \mathrm{w}_{2}=30 \%\right)$ also tested for the other three lakes, corresponded to an exploitation of the available water volume above $90 \%$ and a decrease in the lakes' surface area between $50 \%$ and $90 \%$, which practically would lead to a severe disorder of the aquatic ecosystems, even their disappearance.

Table 2. Estimated minimum water level (Min WL) for lakes Zazari, Chimaditida, Petron, and Vegoritida according to the morphological analysis scenarios.

\begin{tabular}{lcccc}
\hline \multirow{2}{*}{ Scenario of Morphological Analysis } & \multicolumn{4}{c}{ Min WL (m.a.s.l.) } \\
\cline { 2 - 5 } & Zazari & Chimaditida & Petron & Vegoritida \\
\hline envScenario $\left(\mathrm{w}_{1}=30 \%, \mathrm{w}_{2}=70 \%\right)$ & 596.0 & 591.3 & 571.1 & 516.2 \\
eqScenario $\left(\mathrm{w}_{1}=\mathrm{w}_{2}=50 \%\right)$ & 594.9 & 591.2 & 570.3 & 490.9 \\
wuScenario $\left(\mathrm{w}_{1}=70 \%, \mathrm{w}_{2}=30 \%\right)$ & 594.0 & 589.2 & 569.1 & 477.9 \\
\hline
\end{tabular}

\subsection{Macrophytes}

In total, 42 taxa of aquatic macrophytes were recorded in the four studied lakes, 17 of which were helophytes and 25 hydrophytes (Table 3). The largest number of taxa (24) was recorded in Lake Vegoritida, while the smallest (9) in Lake Zazari. Fifteen out of the 42 recorded macrophytic taxa are considered as sensitive to hydrologic alterations (Table 3). However, sufficient information regarding their ecological preferences was available only for nine of them (Table 3), which were selected as indicator species for the water regime preferences of the macrophytic communities. Their water depth habitat suitability curves, which were developed by using the available information from the literature (Appendix A, Table A1) and by expert judgement, are provided in Figure 4. The optimal water depth for each species colonization and reproduction success is very narrow for the majority of the indicator taxa, with the exception of Myriophyllum spicatum (Figure 4). 
Table 3. List of macrophytic taxa recorded in lakes Zazari (Z), Chimaditida (C), Petron (P), and Vegoritida (V) in summer 2016. The taxa sensitive to hydromorphological alterations (HA) are also indicated. Hel-Helophytes; Hyd-Hydrophytes.

\begin{tabular}{|c|c|c|c|c|c|c|}
\hline Taxa & Life Form & Sensitive to $\mathrm{HA}$ & $\mathbf{Z}$ & $\mathrm{C}$ & $\mathbf{P}$ & $\mathbf{V}$ \\
\hline Phragmites australis (Cav.) Steud. & Hel & YES * & $X$ & $X$ & $X$ & $X$ \\
\hline Typha spp. L. & Hel & YES * & & $X$ & $X$ & $X$ \\
\hline Paspalum distichum $\mathrm{L}$. & Hel & & & $x$ & & $x$ \\
\hline Rumex palustris Sm. & Hel & & & $x$ & & $X$ \\
\hline Lycopus europaeus L. & Hel & & & & & $x$ \\
\hline Chaerophyllum bulbosum L. & Hel & & & & & $X$ \\
\hline Mentha aquatica $\mathrm{L}$. & Hel & & $x$ & $x$ & $x$ & \\
\hline Schoenoplectus lacustris (L.) Palla & Hel & YES * & & $x$ & $X$ & \\
\hline Eleocharis mitracarpa Steud. & Hel & YES & & & $x$ & \\
\hline Schoenoplectus litoralis (Schrad.) Palla & Hel & YES & & & $X$ & \\
\hline Stachys palustris L. & Hel & & $X$ & $X$ & & \\
\hline Rorippa amphibia (L.) Besser & Hel & & $x$ & $x$ & & \\
\hline Alisma plantago-aquatica L. & Hel & YES* & & $x$ & & \\
\hline Carex pseudocyperus L. & Hel & YES & & $x$ & & \\
\hline Juncus subnodulosus Schrank & Hel & YES * & & $x$ & & \\
\hline Cyperus longus L. & Hel & YES & $x$ & & & \\
\hline Eleocharis palustris (L.) R. Br. & Hel & YES & $x$ & & & \\
\hline Cladophora spp. Kutz. & Hyd & & $x$ & $x$ & $x$ & $X$ \\
\hline Ceratophyllum demersum L. & Hyd & & & $x$ & $x$ & $X$ \\
\hline Ceratophyllum submersum L. & Hyd & & & & $X$ & $x$ \\
\hline Potamogeton perfoliatus L. & Hyd & & $X$ & & $X$ & $X$ \\
\hline Stuckenia pectinata (L.) Borner & Hyd & & & & $x$ & $x$ \\
\hline Myriophyllum spicatum L. & Hyd & YES * & & & $x$ & $x$ \\
\hline Vallisneria spiralis L. & Hyd & & & & $x$ & $x$ \\
\hline Nitella furcata (Roxb. Ex Bruz.) Ag. & Hyd & & & & $x$ & $x$ \\
\hline Chara tomentosa $\mathrm{L}$. & Hyd & & & & $x$ & $x$ \\
\hline Chara vulgaris L. & Hyd & & & & $X$ & $x$ \\
\hline Lemna minor L. & Hyd & & & $X$ & & $x$ \\
\hline Azolla filliculoides Lam. & Hyd & & & $X$ & & $x$ \\
\hline Spirodella polyrhiza (L.) Scheid. & Hyd & & & $x$ & & $x$ \\
\hline Ranunculus trichophyllus Chaix & Hyd & YES * & $x$ & & & $x$ \\
\hline Lemna gibba L. & Hyd & & & & & $x$ \\
\hline Persicaria amphibia (L.) S. F. Gray & Hyd & & & & & $x$ \\
\hline Potamogeton trichoides Cham. \& Schltdl. & Hyd & YES & & & & $x$ \\
\hline Alisma gramineum Lej. & Hyd & YES * & & & & $x$ \\
\hline Utricularia vulgaris L. & Hyd & & & $x$ & $x$ & \\
\hline Najas marina L. & Hyd & & & & $x$ & \\
\hline Chara hispida $\mathrm{L}$. & Hyd & & & & $x$ & \\
\hline Zannichellia palustris L. & Hyd & YES * & & & $x$ & \\
\hline Nitellopsis obtus $\alpha$ (Desv. In Lois.) J. Gr. & Hyd & & & & $x$ & \\
\hline Hydrocharis morsus-ranae L. & Hyd & & & $x$ & & \\
\hline Lemna trisulca L. & Hyd & & & $x$ & & \\
\hline Total & 42 & 15 & 9 & 19 & 21 & 24 \\
\hline
\end{tabular}

${ }^{*}$ taxa for which information regarding their tolerance in water level fluctuations is available. 

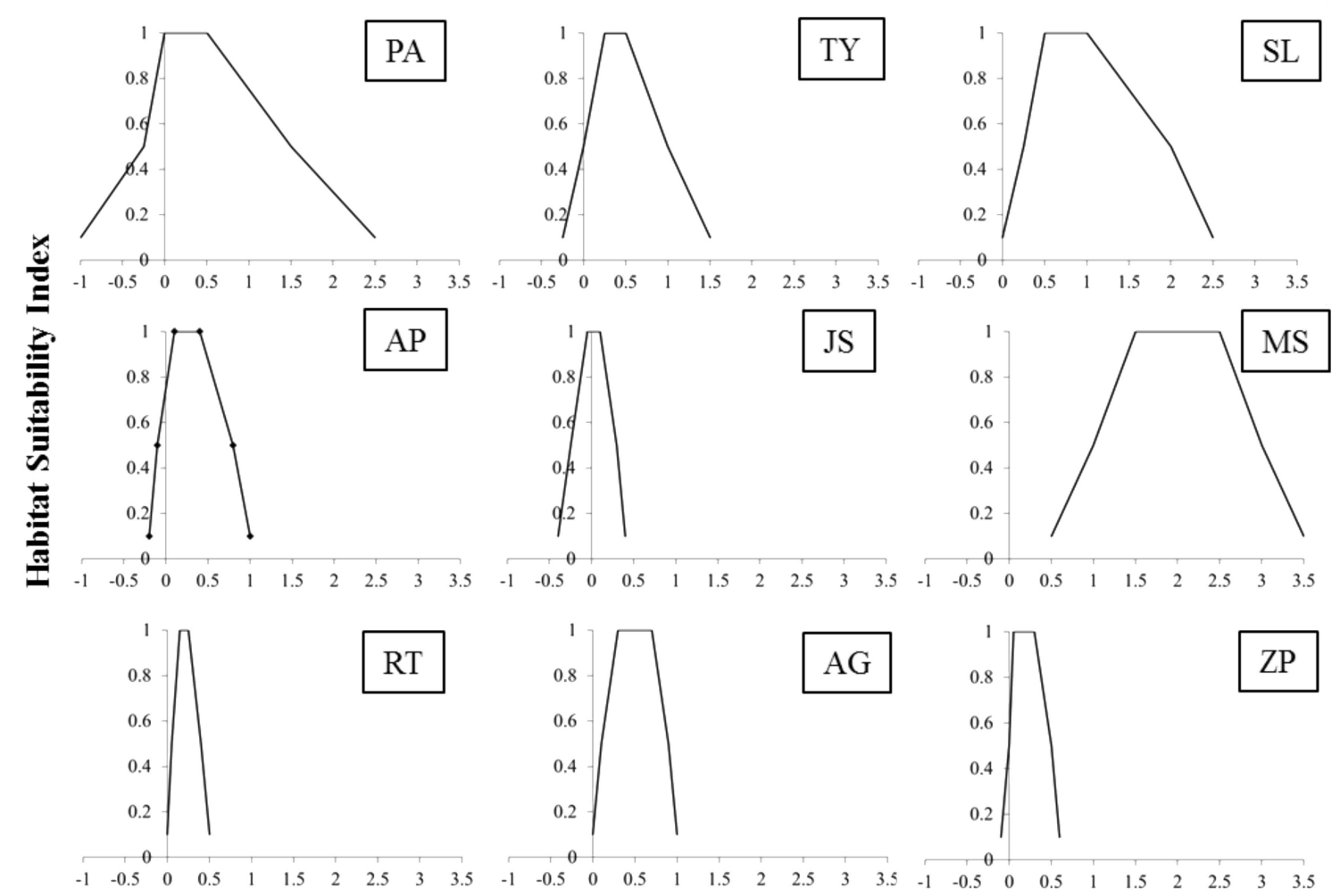

\section{Water depth (m)}

Figure 4. Habitat suitability curves in relation to water depth for the selected macrophytic indicator taxa: (PA) Phragmites australis, (TY) Typha spp., (SL) Schoenoplectus lacustris, (AP) Alisma plantago-aquatica, (JS) Juncus subnodulosus, (MS) Myriophyllum spicatum, (RT) Ranunculus trichophyllus, (AG) Alisma gramineum, and (ZP) Zannichellia palustris.

In Table 4, we provide the abundances estimated per depth zone for each indicator species. P. australis was recorded in all four lakes and was abundant in the littoral zone of the three shallower lakes. In particular, the species dominated the depth zone 0-1.4 $\mathrm{m}$ in Lake Petron, while in lakes Chimaditida and Zazari, the depth zones were 0-1.6 and 0-3.2 m, respectively (Table 4). In Lake Zazari, macrophytic diversity was relatively poor in both species richness and abundance due to eutrophication pressures, resulting in extremely low water clarity and high phytoplankton biomass. However, the existence of the relatively sensitive to water depth changes species Ranunculus trichophyllus indicates mild water fluctuations at least during recent years [63]. The same was also indicated by the rich and robust helophytic vegetation found in Lake Chimaditida and the presence of $P$. australis reed beds around Lake Petron along with the presence of taxa more sensitive to water level fluctuations (e.g., Typha spp., Schoenoplectus lacustris, Schoenoplectus litoralis, Zannichellia palustris) in the shallow areas of the littoral zone. These mild water level fluctuations resulted in the sustainment of constant shallow water areas suitable for helophytic development.

\subsection{Fish Fauna}

A total of 22 fish species have been reported in the studied lakes, 9 of which were introduced in the inland waters of Greece (Table 5). However, the species Oncorhynchus kisutch (Walbaum, 1792), Oncorhynchus mykiss (Walbaum, 1792), Salvelinus fontinalis (Mitchill, 1814), and Salmo cf. trutta that were introduced in 1950-1960 to enhance fisheries [64] did not establish permanent populations and they are nowadays considered as extinct (personal communication with local professional fishermen). Only the species Coregonus cf. lavaretus, which was also introduced in the same period, was established 
in Lake Vegoritida, where it is economically exploited. The native species E. lucius and C. carpio also have economic importance as well as $R$. rutilus and P. fluviatilis (to a lesser extent).

Table 4. Abundance per depth-zone (1: 0-1 m; 2: 1-2 m; 3: 2-4 m; 4: 4-8 m) of the selected macrophytic indicator taxa. D-Dominant > 75\%; A-Abundant 25-75\%; F-Frequent 10-25\%; O-Occasional $1-10 \%$; R-Rare $<1 \%$.

\begin{tabular}{lcccccccccccccc}
\hline \multirow{2}{*}{ Taxa } & \multicolumn{3}{c}{ Zazari } & \multicolumn{3}{c}{ Chimaditida } & \multicolumn{3}{c}{ Petron } & \multicolumn{3}{c}{ Vegoritida } \\
\cline { 2 - 13 } & $\mathbf{1}$ & $\mathbf{2}$ & $\mathbf{3}$ & $\mathbf{1}$ & $\mathbf{2}$ & $\mathbf{3}$ & $\mathbf{1}$ & $\mathbf{2}$ & $\mathbf{3}$ & $\mathbf{1}$ & $\mathbf{2}$ & $\mathbf{3}$ & $\mathbf{4}$ \\
\hline P. australis & $\mathrm{A}$ & $\mathrm{A}$ & $\mathrm{F}$ & $\mathrm{A}$ & $\mathrm{A}$ & $\mathrm{R}$ & $\mathrm{A}$ & $\mathrm{F}$ & - & $\mathrm{O}$ & $\mathrm{R}$ & $\mathrm{O}$ & $\mathrm{O}$ \\
Typha spp. & - & - & - & $\mathrm{O}$ & $\mathrm{O}$ & - & $\mathrm{R}$ & $\mathrm{R}$ & - & $\mathrm{O}$ & $\mathrm{R}$ & - & - \\
S. lacustris & - & - & - & $\mathrm{O}$ & - & - & $\mathrm{O}$ & $\mathrm{R}$ & - & - & - & - & - \\
A. plantago-aquatica & - & - & - & $\mathrm{R}$ & - & - & - & - & - & - & - & - & - \\
J. subnodulosus & - & - & - & $\mathrm{R}$ & - & - & - & - & - & - & - & - & - \\
M. spicatum & - & - & - & - & - & - & $\mathrm{R}$ & $\mathrm{R}$ & $\mathrm{R}$ & $\mathrm{R}$ & $\mathrm{O}$ & $\mathrm{F}$ & $\mathrm{O}$ \\
R. trichophyllus & $\mathrm{R}$ & - & - & - & - & - & - & - & - & $\mathrm{R}$ & $\mathrm{R}$ & $\mathrm{R}$ & - \\
A. gramineum & - & - & - & - & - & - & - & - & - & $\mathrm{R}$ & - & - & - \\
Z. palustris & - & - & - & - & - & - & $\mathrm{R}$ & - & - & - & - & - & - \\
\hline
\end{tabular}

Table 5. Fish species reported in lakes Zazari (Z), Chimaditida (C), Petron (P), and Vegoritida (V). Some characteristics of their life history traits are also presented.

\begin{tabular}{|c|c|c|c|c|c|c|c|c|c|c|c|c|c|c|c|c|c|c|c|}
\hline \multirow{2}{*}{ Family/Species } & \multirow{2}{*}{$\mathbf{Z}$} & \multirow{2}{*}{ C } & \multirow{2}{*}{$\mathbf{P}$} & \multirow{2}{*}{$\mathbf{V}$} & \multirow{2}{*}{ Reproductive Substrate } & \multirow{2}{*}{ Trophic Guild } & \multirow{2}{*}{ Habitat } & \multicolumn{12}{|c|}{ Reproductive Period } \\
\hline & & & & & & & & 1 & 2 & 3 & 4 & 5 & 6 & 7 & 8 & 9 & 10 & 11 & 12 \\
\hline Centrarchidae & & & & & & & & & & & & & & & & & & & \\
\hline L. gibbosus & & I & I & I & LITH & INV & WCOL & & & & + & + & + & & & & & & \\
\hline Cyprinidae & & & & & & & & & & & & & & & & & & & \\
\hline A. thessalicus & & $\mathrm{N}$ & & $\mathrm{N}$ & PHLI & PLAN & WCOL & & & & & $(+)$ & $(+)$ & $(+)$ & & & & & \\
\hline B. balcanicus * & $\mathrm{N}$ & $\mathrm{N}$ & & $\mathrm{N}$ & LITH & INV & WCOL & & & & & + & + & + & & & & & \\
\hline C. gibelio & I & I & $\mathrm{I}$ & I & PHYT & OMNI & BENT & & & & & + & + & + & & & & & \\
\hline C. carpio & $\mathrm{N}$ & $\mathrm{N}$ & $\mathrm{N}$ & $\mathrm{N}$ & PHYT & OMNI & BENT & & & & & + & + & + & & & & & \\
\hline G. bulgaricus * & & & & $\mathrm{N}$ & PSAM & INV & WCOL & & & & & + & + & & & & & & \\
\hline P. macedonicum & $\mathrm{N}$ & $\mathrm{N}$ & $\mathrm{N}$ & $\mathrm{N}$ & PHLI & INV & WCOL & & & & & + & + & & & & & & \\
\hline P. parva & & I & & & PHLI & OMNI & WCOL & & & & + & + & + & & & & & & \\
\hline R. meridionalis & $\mathrm{N}$ & $\mathrm{N}$ & $\mathrm{N}$ & $\mathrm{N}$ & OSTR & OMNI & WCOL & & & & $(+)$ & $(+)$ & $(+$ & & $(+)$ & & & & \\
\hline R. rutilus & $\mathrm{N}$ & $\mathrm{N}$ & $\mathrm{N}$ & $\mathrm{N}$ & PHLI & OMNI & WCOL & & & & + & + & & & & & & & \\
\hline S. erythrophthalmus ** & & & & $\mathrm{N}$ & PHYT & OMNI & WCOL & & & & + & + & + & & & & & & \\
\hline S. vardarensis & & & & $\mathrm{N}$ & LITH & OMNI & WCOL & & & & $(+)$ & $(+)$ & $(+)$ & & & & & & \\
\hline T. tinca & $\mathrm{N}$ & $\mathrm{N}$ & $\mathrm{N}$ & $\mathrm{N}$ & PHYT & OMNI & BENT & & & & + & + & + & + & & & & & \\
\hline Esocidae & & & & & & & & & & & & & & & & & & & \\
\hline E. lucius & $\mathrm{N}$ & $\mathrm{N}$ & $\mathrm{N}$ & $\mathrm{N}$ & PHYT & PISC & WCOL & & + & + & + & + & + & & & & & & \\
\hline Percidae & & & & & & & & & & & & & & & & & & & \\
\hline P. fluviatilis & $\mathrm{N}$ & $\mathrm{N}$ & $\mathrm{N}$ & $\mathrm{N}$ & PHLI & INV/PISC & WCOL & & + & + & + & + & + & + & & & & & \\
\hline Poeciliidae & & & & & & & & & & & & & & & & & & & \\
\hline G. holbrooki & I & I & & I & OVI & INV & WCOL & & & & + & + & + & + & + & + & + & & \\
\hline Salmonidae & & & & & & & & & & & & & & & & & & & \\
\hline C. cf lavaretus & & & & I & LITH & INV & WCOL & + & + & & & & & & & & & & + \\
\hline O. kisutch * & & & & I & - & - & - & & & & & & & & & & & & \\
\hline O. mykiss * & & I & & I & - & - & - & & & & & & & & & & & & \\
\hline S. fontinalis * & & & & I & - & - & - & & & & & & & & & & & & \\
\hline S. cf. trutta* & & & & I & - & - & - & & & & & & & & & & & & \\
\hline Siluridae & & & & & - & - & - & & & & & & & & & & & & \\
\hline S. glanis & & & & $\mathrm{N}$ & PHYT & PISC & WCOL & & & & + & + & + & & & & & & \\
\hline
\end{tabular}

* The species is likely extinct. ${ }^{* *}$ It is not clear that the species exists or if it is mistakenly confused with R. rutilus. N-native; I-introduced; BENT—benthic; INV—invertivorous; LITH—lithophilic; OVI—oviviparous; OMNI—omnivorous; OSTR—ostracophilic; PHLI—phyto-lithophilic; PHYT—phytophilic; PISC—piscivorous; PLAN-planktivorous; PSAM-psammophilic; WCOL—benthopelagic. With $(+)$ the reproductive months of species based on closest relative. 1-January; 2-February; ... , 12-December.

The majority of the fish species are reproduced mainly in the riparian zone during spring, except $C$. cf. lavaretus, which spawns from December to February (Table 5), also using the riparian zone (personal communication with local fisherman). Most fish species, regarding their preferences upon the reproduction substrate, are phytophilic (33.3\%). When their diet preferences are considered, the majority (44.4\%) are omnivorous, while $83.3 \%$ of the species use the whole water column as a habitat (Table 5). 


\subsection{Ecological Water Level}

Morphological analysis revealed that only the scenario envScenario $\left(\mathrm{w}_{1}=30 \%, \mathrm{w}_{2}=70 \%\right)$, according to which biodiversity conservation is favored against water use, provided reliable and realistic estimates regarding the minimum ecological water level, thus it is the preferred scenario among the three tested for all studied lakes (Figure 5, Table A2). Adopting the eqScenario or wuScenario scenarios would lead to shrinkage or disappearance of the studied lakes, without the possibility of their replenishment with water by their catchment area.

\section{Zazari}

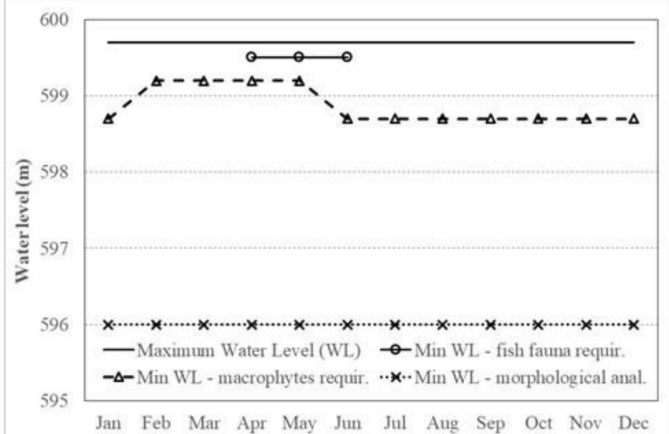

Petron

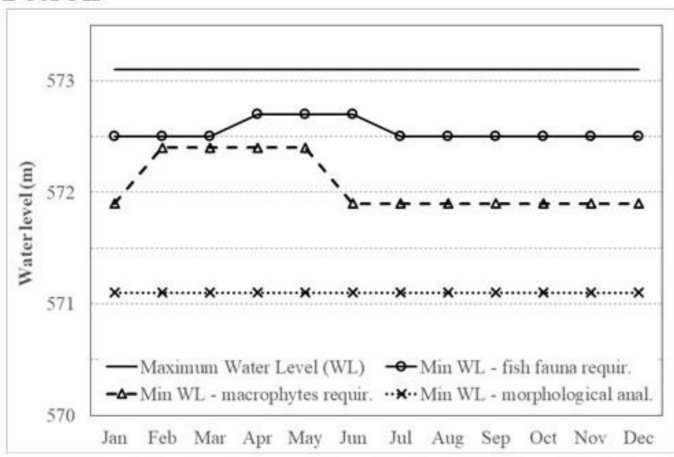

Chimaditida

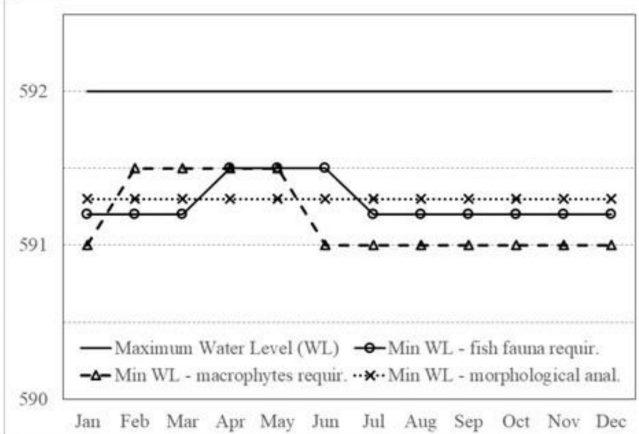

Vegoritida

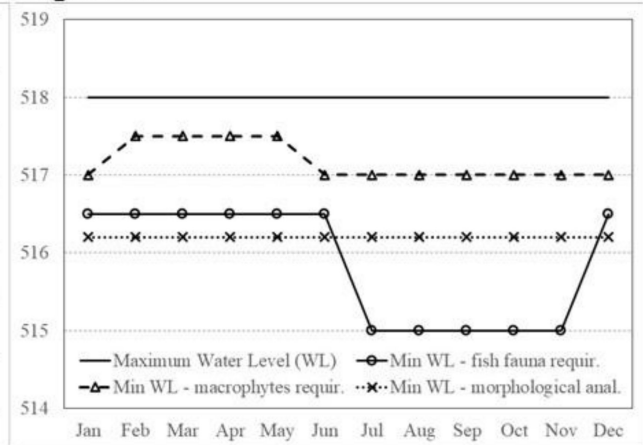

Figure 5. Proposed minimum water level based on the morphological analysis and the requirements of macrophytes and fish in Lakes Zazari, Chimaditida, Petron, and Vegoritida.

The newly developed seedlings (of perennial and annual aquatic species) need a water level rise of some decimeters during springtime, in order to continue developing in the water column. This, along with the lakes' water regime, guided the suggestions concerning the lakes' minimum water level based on macrophytes (Figure 5, Table A2). These suggestions would allow the creation of semi-permanent shallow water areas that would consequently allow the establishment of more helophytic and shallow water hydrophytic species, raising the biodiversity that the lakes sustain. This in turn is expected to result in the creation of broader reproductive fields for fish and in general, to keep the number of shoreline microhabitats high, allowing the sustainment of greater biodiversity.

In more detail, the proposed minimum water level based on macrophytes' requirements during the dry season (June to January) for Lake Zazari was set at 598.7 m.a.s.l. and during the wet period (February to May) at 599.2 m.a.s.l. (Table A2). This water level would allow the conservation of the $P$. australis reed beds which would remain in depths between 0 and $2.7 \mathrm{~m}$ during the dry period, as well as the protection of the shallow water areas where R. trichophyllus was present.

During macrophyte sampling, the biggest proportion of Lake Chimaditida had a water depth of less than $1 \mathrm{~m}$. Exposing this area outside the water column would provoke rapid changes to the lake's macrophytic vegetation and consequently, to the biodiversity that the lake sustains. Therefore, based on macrophytic vegetation's requirements, the lake's minimum water level during the dry season should be higher than 591 m.a.s.l. (Table A2) and consequently, higher than 591.5 m.a.s.l. during 
the wet period. Initially, these water levels would allow the maintenance of the lake's continuity in its shallow areas and the presence of open water areas. In addition, they would allow the conservation of the P. australis reed beds, which will remain in depths up to $0.7 \mathrm{~m}$ during the dry period, and the robustness of Typha spp. and S. lacustris individuals in water depths a little above $0.3 \mathrm{~m}$, which is in the boundaries of desirable habitat suitability for these species. Moreover, these water levels in Lake Chimaditida would allow the protection of shallow water areas between dense reed beds and the lake's embankment, where A. plantago-aquatica and J. subnodulosus are present. A drop in the lake's water level of $0.5 \mathrm{~m}$ would allow at least a $10 \mathrm{~cm}$ water depth in these areas, permitting the species' development.

As mentioned above, the seedlings of the macrophyte indicator species (previous year's perennial species and present year's annual species) require approximately $0.5 \mathrm{~m}$ water depth during early springtime. Therefore, a minimum water level of 572.4 m.a.s.l. during the wet period and of 571.9 m.a.s.l. during the dry period should be maintained in Lake Petron. These water levels would allow the conservation of the P. australis reed beds (assuring their presence in a water depth of up to $0.6 \mathrm{~m}$ during the dry period) and of the robust individuals of Typha spp. and S. lacustris, by ensuring their presence in an optimal water depth considering their requirements (a little above $0.2 \mathrm{~m}$ ). Moreover, they would allow the unobstructed development of M. spicatum beds, which were recorded in depths of 1.8 to $3 \mathrm{~m}$. These beds (under the proposed water regime) would be found at a depth between 1 and $2.2 \mathrm{~m}$ during the dry period, which is more desirable for the species. Finally, this water regime would protect the shallow areas by maintaining at least a $10 \mathrm{~cm}$ water depth during spring for the development of Z. palustris.

The minimum water level for Lake Vegoritida, based on macrophytic requirements, should be around 517 m.a.s.l. in the dry period and around 517.5 m.a.s.l. in the wet one (Table A2). These water levels would allow the conservation of the healthy P. australis reed beds (found between 1.6 and $3 \mathrm{~m}$ water depth during samplings) by maintaining a water depth between 0 and $1.4 \mathrm{~m}$ for them during the dry period, which is the optimal water depth considering species' habitat suitability. Moreover, these water levels would ensure the survival and reproduction of the robust individuals of Typha spp. (recorded in depths from 1.2 to $1.8 \mathrm{~m}$ during samplings) by maintaining a water depth above $0.2 \mathrm{~m}$ during summer for them, which is an acceptable water depth considering species' habitat suitability. In addition, optimal growth and reproduction of the species $R$. trichophyllus would also be conserved in the more suitable water depth of less than $0.5 \mathrm{~m}$ during the spring period (in contrast to the $0.8-1.6 \mathrm{~m}$ water depth that was recorded during samplings) and of M. spicatum (recorded in depths of 1.8 to $5.2 \mathrm{~m}$ ), as under the proposed water regime, the species is expected to be found at depths of 0.2 to $3.6 \mathrm{~m}$. This range is quite close to that of the species' optimal habitat. Last, these levels would ensure the sustainable survival of the hydrophytic species A. gramineum, since at least some individuals would remain during spring at depths less than $1 \mathrm{~m}$.

Fish fauna conservation in the studied lakes necessitates the protection of species' reproductive and nursery fields. Since most fish species that are present in the studied lakes are phytophilic, areas with dense macrophytic vegetation should be present and accessible by fish during spring, for ensuring their successful reproduction. However, $22.2 \%$ of the species are lithophilic, which reveals that areas with gravel, rocky, and sandy substrate should also be available for their reproduction. For this framework, the protection of the littoral and riparian zone habitats is of critical importance for the sustainability of lakes' fish fauna. Therefore, excessive water level fluctuations should be avoided mainly during the species' reproductive period (ensuring accessibility to the reproductive fields and avoiding eggs' exposure to air).

Based on the above, a maximum water level fluctuation of up to $0.5 \mathrm{~m}$ is acceptable for the three shallower lakes during species reproduction (Figure 5, Table A2). However, in Lake Zazari, an even smaller water level fluctuation would be preferred during this period (i.e., the minimum water level should be around 599.6 m.a.s.l., Figure 5, Table A2). This would allow a water depth of about $20 \mathrm{~cm}$ to be retained in the reed beds that cover a large area in the North East part of the lake, funcioning as 
a valuable reproductive and nursery field for fish. A smaller water depth would excessively reduce the use of reed beds by fish which may result in a reduction in many cyprinid larvae survival as was observed after an extensive reduction in reed beds in a Chinese lake [32].

Similarly, in Lake Chimaditida, the water level should remain above 591.2 m.a.s.l. (Figure 5, Table A2) during the fish species' reproductive period for ensuring at least a small water depth in the shallowest western part of the lake, which is of significant importance for fish reproduction.

In Lake Petron, considering the reproductive period of the hosted fish, the water level should keep relatively stable during spring to mid-summer and above 572.5 m.a.s.l. all year long (Figure 5, Table A2).

Finally, in Lake Vegoritida, the water level should remain above 515 m.a.s.l. (as was achieved in recent years) with a desirable maximum water level up to 518 m.a.s.l. (Figure 5, Table A2). However, a relatively stable water level (maximum fluctuation amplitude of about 1-1.5 m) should be retained during both spring (for the reproduction of fish species majority) and winter (especially from December to February) to ensure the reproductive success of $C$. cf. lavaretus. During these months, the species should have access to shallow areas of about 1.5-3 m depth with gravel substrate.

Due to its distinct reproductive period, the species $C$. cf. lavaretus could serve as an indicator, the monitoring of which would allow the relatively early detection of water level alterations that would probably affect fish. Based on fish traits and regarding their abundance and economical importance, E. lucius and C. carpio could also be used as indicator species. The three species represent almost all reproductive patterns (phytophilic, lithophilic), diet (omnivorous, piscivorous, inventivorous), and habitat preferences (C. carpio prefers to remain near the substrate (benthic), while the other two use the whole water column). Moreover, their reproductive period lasts from December to August, covering thus the crucial period when the largest water level fluctuations are observed. However, as a lag effect in the response of the biological communities to the water regime alteration is expected [18], the impacts of the water regime on species reproduction would probably be revealed years later, based on recruitment results. Therefore, a fish fauna monitoring program conducted every 3 years using multi-mesh gillnets as proposed by [65] for sampling the fish fauna of lake water bodies would be efficient in detecting the imposed effects. In addition, since these species are of economic importance, information regarding their reproductive success, recruitment, and abundance could also be provided by local fishermen and commercial landing data.

\section{Conclusions}

The differences observed in the results of the morphological analysis and the analyses of both fish and macrophyte requirements in the studied lakes revealed the necessity for a holistic approach regarding the assessment of the ecological water level of the complicated lake ecosystems that has to incorporate all available parameters, which describe their function. The morphological analysis highlighted the unique characteristics of each lake regarding the water depth (shallow or deep lake) and the bottom slope (mild or steep) but this should be carefully used as it can lead to unrealistic or misleading assessments of minimum water level. In addition, even though the morphological analysis is straightforward, it does not reflect the biological function of the lake. Therefore, the methodology followed here could provide useful guidance for assessing the ecological water regimes of lake ecosystems. However, further research should take place targeting the development of tools that would be able to provide quantitative forecasts of the impacts that the water regime deviations from the natural pattern would have on biological communities. In this framework, model scenarios could be used to study the trade-offs between biocommunities and different water regimes, guiding the management measures in manipulating the water level throughout the year in order to manipulate the fish fauna community, as has previously been proved for river systems [66].

Author Contributions: O.P.: investigation, validation, visualization, writing一original draft preparation; D.Z.: investigation, validation, writing; C.D.: project administration, conceptualization, visualization, writing-review 
and editing; D.B.: conceptualization, writing-review and editing. All authors have read and agreed to the published version of the manuscript.

Funding: This work is based on the project "Improving the knowledge in determining the minimum water level and flow of water bodies" (http://eordaia-nestos.gr/en), which was financed by the European Economic Area Financial Mechanism 2009-2014 and the Public Investment Program.

Conflicts of Interest: The authors declare no conflict of interest.

\section{Appendix A}
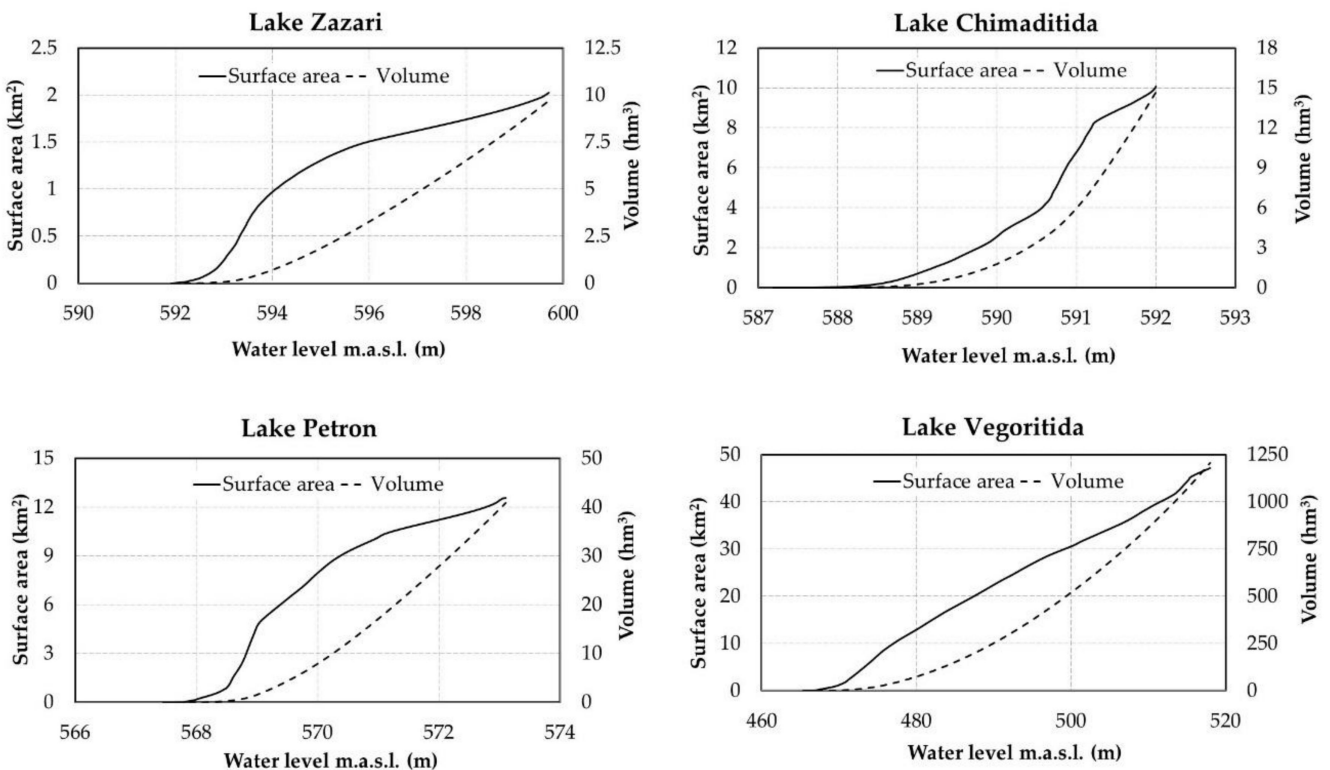

Figure A1. Water level surface area-volume curves of Lakes Zazari, Chimaditida, Petron, and Vegoritida.

Table A1. The literature used for the determination of water depth preferences of macrophyte plant indicator species.

Phragmites australis

- $\quad$ Batriu, E.; Ninot, J.M.; Pino, J. Interactions between transplants of Phragmites australis and Juncus acutus in Mediterranean coastal marshes: The modulating role of environmental gradients. Aquat. Bot. 2015, 124, 29-38.

- $\quad$ Blanch, S.J.; Ganf, G.G.; Walker, K.F. Tolerance of riverine plants to flooding and exposure indicated by water regime. Regulated Rivers: Research \& Management: An International Journal Devoted to River Research and Management, 1999, 15, 43-62.

- Coops, H.; Geilen, N.; van der Velde, G. Helophyte zonation in two regulated estuarine areas in the Netherlands: Vegetation analysis and relationships with hydrological factors. Estuaries, 1999, 22, 657-668.

- Coops, H.;van der Velde, G. Impact of hydrodynamic changes on the zonation of helophytes. Neth. J. Aquat. Ecol. 1996, 30, 165-173.

- Coops, H.; Vulink, J.T.; van Nes, E.H. Managed water level and the expansion of emergent vegetation along a lakeshore. Limnologica, 2004, 34, 57-64.

- $\quad$ Deegan, B.M.; White, S.D.; Ganf, G.G. The influence of water level fluctuations on the growth of four emergent macrophyte species. Aquat. Bot. 2007, 86, 309-315.

- $\quad$ Greet, J.; Rees, P. Slashing may have potential for controlling Phragmites australis in long-inundated parts of a Ramsar-listed wetland. Ecol. Manag. Restor. 2015, 16-3, 233-236.

- Mauchamp, A.; Blanch, S.; Grillas, P. Effects of submergence on the growth of Phragmites australis seedlings. Aquat. Bot. 2001, 69, 147-164.

- $\quad$ Poulin, B.; Lefebvre, G.; Mauchamp, A. Habitat requirements of passerines and reedbed management in southern France. Biol. Conserve. 2002, 107, 315-325.

- $\quad$ Qi, M.; Sun, T.; Zhan, M.; Xue, S.F. Simulating dynamic vegetation changes in a tidal restriction area with relative stress tolerance curves. Wetlands, 2016, 36, S31-S43.

- $\quad$ Sutherland, W.J.; Hill, D.A. Managing habitats for conservation. Cambridge University Press, The Pitt Building, Trumpington Street, Cambridge, United Kingdom, 1995.

- Weisner, S.E.B.; Ekstam, B. Influence of germination time on juvenile performance of Phragmites australis on temporarily exposed bottoms-implications for the colonization of lake beds. Aquat. Bot. 1993, 45, 107-118. 
Table A1. Cont.

Typhaspp.

- Blanch, S.J.; Ganf, G.G.; Walker, K.F. Tolerance of riverine plants to flooding and exposure indicated by water regime. Regulated Rivers: Research \& Management: An International Journal Devoted to River Research and Management, 1999, 15, 43-62.

- Coops, H.; Geilen, N.; van der Velde, G. Helophyte zonation in two regulated estuarine areas in the Netherlands: Vegetation analysis and relationships with hydrological factors. Estuaries, 1999, 22, 657-668.

- Coops, H.; van der Velde, G. Impact of hydrodynamic changes on the zonation of helophytes. Neth. J. Aquat. Ecol. 1996, 30, 165-173.

- Coops, H.; Vulink, J.T.; van Nes, E.H. Managed water level and the expansion of emergent vegetation along a lakeshore. Limnologica, 2004, 34, 57-64.

- Deegan, B.M.; White, S.D.; Ganf, G.G. The influence of water level fluctuations on the growth of four emergent macrophyte species. Aquat. Bot. 2007, 86, 309-315.

- Inoue, T.; Tsuchiya, T. Depth distribution of three Typha species, Typha orientalis Presl, Typha angustifolia L. and Typha latifolia L., in an artificial pond. Plant Species Biol. 2009, 24, 47-52.

- Sutherland, W.J.; Hill, D.A. Managing habitats for conservation. Cambridge University Press, The Pitt Building, Trumpington Street, Cambridge, United Kingdom, 1995.

- Watt, S.C.L.; Garcia-Berthou, E.; Vilar, L. The influence of water level and salinity on plant assemblages of a seasonally flooded Mediterranean wetland. Plant Ecol. 2007, 189, 71-85.

Schoenoplectus lacustris

- Coops, H.; Geilen, N.; van der Velde, G. Helophyte zonation in two regulated estuarine areas in the Netherlands: Vegetation analysis and relationships with hydrological factors. Estuaries, 1999, 22, 657-668.

- Coops, H.; van den Brink, F.W.B.; van der Velde, G. Growth and morphological responses of four helophyte species in an experimental water-depth gradient. Aquat. Bot. 1996, 54, 11-24.

- Coops, H.; van der Velde, G. Impact of hydrodynamic changes on the zonation of helophytes. Neth. J. Aquat. Ecol. 1996, $30,165-173$

- Weisner, S.E.B.; Ekstam, B. Influence of germination time on juvenile performance of Phragmites australis on temporarily exposed bottoms-implications for the colonization of lake beds. Aquat. Bot. 1993, 45, 107-118.

Juncus subnodulosus

- $\quad$ Richards, P.W.; Clapham, A.R. Juncus subnodulosus Schrank (J. obtusiflorus Ehrh.). J. Ecol. 1941, 29, 385-391.

Alisma plantago-aquatica

- $\quad$ Keddy, P.A.; Ellis, T.H. Seedling recruitment of 11 wetland plant species along a water level gradient: shared or distinct responses? Can. J. Bot. 1985, 63, 1876-1879.

- $\quad$ Moravcova, L.; Zakravsky, P.; \& Hroudova, Z. Germination and seedling establishment in Alisma gramineum, A. plantago-aquatica and A. lanceolatum under different environmental conditions. Folia Geobot. 2001, 36, 131-146.

- Watt, S.C.L.; Garcia-Berthou, E.; Vilar, L. The influence of water level and salinity on plant assemblages of a seasonally flooded Mediterranean wetland. Plant Ecol. 2007, 189, 71-85.

Myriophyllum spicatum

- $\quad$ Feldmann, T.; Noges, P. Factors controlling macrophyte distribution in large shallow Lake Vortsjarv. Aquat. Bot. 2007, $87,15-21$

- $\quad$ Smith, C.S.; Barko, J. Ecology of Eurasian watermilfoil. J. Aquat. Plant Manag. 1990, 28, 55-64

- $\quad$ Strand, J.A.; Weisner, S.E. Morphological plastic responses to water depth and wave exposure in an aquatic plant (Myriophyllum spicatum). J. Ecol. 2001, 89, 166-175.

- $\quad$ van den Berg, M.S.; Joosse, W.; Coops, H. A statistical model predicting the occurrence and dynamics of submerged macrophytes in shallow lakes in the Netherlands. Hydrobiologia, 2003, 506-509, 611-623.

- Wang, P.; Zhang, Q.; Xu, Y.S.; Yu, F.H. Effects of water level fluctuation on the growth of submerged macrophyte communities. Flora, 2016, 223, 83-89.

Ranunculus trichophyllus

- Hartog, C.; Segal, S. A new classification of the water-plant communities. Acta Bot. Neer. 1964, 13, 367-393.

- Hong, D.Y. A biosystematic study on Ranunculus subgenus Batrachium in S Sweden. Nor. J. Bot. 1991, 11, 41-59.

- $\quad$ Lumbreras, A.; Olives, A.; Quintana, J.R.; Pardo, C.; Molina, J.A. Ecology of aquatic Ranunculus communities under the Mediterranean climate. Aquat. Bot. 2009, 90, 59-66.

- Zander, B.; Wiegleb, G. Biosystematische untersuchungen an populationen von Ranunculus subgen Batrachium in Nordwest-Deutchland. Bot. Jahrb. Syst. 1987, 109, 81-130.

\section{Alisma gramineum}

- $\quad$ Moravcova, L.; Zakravsky, P.; Hroudova, Z. Germination and seedling establishment in Alisma gramineum, A. plantago-aquatica and A. lanceolatum under different environmental conditions. Folia Geobot. 2001, 36, 131-146. 
Table A1. Cont.

Zannichellia palustris

- $\quad$ van Vierssen, W. The ecology of communities dominated by Zannichellia taxa in western Europe. II. Distribution, synecology and productivity aspects in relation to environmental factors. Aquat. Bot. 1982, 13, 385-483.

- $\quad$ Vogiazakis, I.N.; Kazakis, G.; Ghosn, D. Macrophyte community structure and species occurrence in relation to environmental determinants in the ephemeral aquatic habitats of Gavdos, Greece. Hydrobiologia, 2009, 630, 127-138.

- Watt, S.C.L.; Garcia-Berthou, E.; Vilar, L. The influence of water level and salinity on plant assemblages of a seasonally flooded Mediterranean wetland. Plant Ecol. 2007, 189, 71-85.

Table A2. Minimum suggested water level (WL) and corresponding surface area and stored volume, based on morphological analysis, macrophytes, and fish requirements in lakes Zazari, Chimaditida, Petron, and Vegoritida.

\begin{tabular}{|c|c|c|c|c|c|}
\hline Parameter & Altitude (m.a.s.l.) & Surface Area $\left(\mathrm{km}^{2}\right)$ & Volume $\left(10^{6} \mathrm{~m}^{3}\right)$ & Surface Area (\%) & Stored Volume (\%) \\
\hline \multicolumn{6}{|c|}{ Lake Zazari } \\
\hline Max WL & 599.7 & 2.03 & 9.71 & & \\
\hline Min WL-fish fauna-April-June & 599.5 & 1.98 & 9.31 & $-2.5 \%$ & $-4.1 \%$ \\
\hline Min WL-fish fauna-July-March & 599.5 & & & & \\
\hline Min WL_-macrophytes-June-January & 598.7 & 1.83 & 7.79 & $-9.9 \%$ & $-19.8 \%$ \\
\hline Min WL-macrophytes-February-May & 599.2 & & & & \\
\hline Min WL_-morphological analysis & 596.0 & 1.51 & 3.31 & $-25.6 \%$ & $-65.9 \%$ \\
\hline \multicolumn{6}{|c|}{ Lake Chimaditida } \\
\hline Max WL & 592.0 & 10.08 & 14.70 & & \\
\hline Min WL-fish fauna-April-June & 591.5 & & & & \\
\hline Min WL_fish fauna-July-March & 591.2 & 8.10 & 7.45 & $-19.6 \%$ & $-49.3 \%$ \\
\hline Min WL-macrophytes-June-January & 591.0 & 6.79 & 5.97 & $-32.6 \%$ & $-59.4 \%$ \\
\hline Min WL-macrophytes-February-May & 591.5 & & & & \\
\hline Min WL_-morphological analysis & 591.3 & 8.36 & 7.95 & $-17.1 \%$ & $-45.9 \%$ \\
\hline \multicolumn{6}{|c|}{ Lake Petron } \\
\hline Max WL & 573.1 & 12.56 & 40.83 & & \\
\hline Min WL-fish fauna-April-June & 572.7 & & & & \\
\hline Min WL-fish fauna-July-March & 572.5 & 11.68 & 33.58 & $-7.0 \%$ & $-17.8 \%$ \\
\hline Min WL-macrophytes-June-January & 571.9 & 11.13 & 26.74 & $-11.4 \%$ & $-34.5 \%$ \\
\hline Min WL-macrophytes-February-May & 572.4 & & & & \\
\hline Min WL—morphological analysis & 571.1 & 10.34 & 18.14 & $-17.7 \%$ & $-55.6 \%$ \\
\hline \multicolumn{6}{|c|}{ Lake Vegoritida } \\
\hline Max WL & 518.0 & 47.15 & 1206.16 & & \\
\hline Min WL_fish fauna-April-June * & 515.0 & 44.27 & 1068.14 & $-6.1 \%$ & $-11.4 \%$ \\
\hline Min WL-fish fauna-July-March * & 515.0 & & & & \\
\hline Min WL_-macrophytes-June-January & 517.0 & 46.45 & 1159.37 & $-1.5 \%$ & $-3.9 \%$ \\
\hline Min WL-macrophytes-February-May & 517.5 & & & & \\
\hline Min WL-morphological analysis & 516.2 & 45.89 & 1123.81 & $-2.7 \%$ & $-6.8 \%$ \\
\hline
\end{tabular}

* the water level should remain above 515 m.a.s.l. with a desirable maximum water level up to 518 m.a.s.l. but the maximum fluctuation amplitude should be restricted to 1-1.5 m during species reproduction period.

\section{References}

1. Naselli-Flores, L.; Barone, R. Water-level fluctuations in Mediterranean reservoirs: Setting a dewatering threshold as a management tool to improve water quality. Hydrobiologia 2005, 548, 85-99. [CrossRef]

2. Zohary, T.; Ostrovsky, I. Ecological impacts of excessive water level fluctuations in stratified freshwater lakes. Inland Waters 2011, 1, 47-59. [CrossRef]

3. Cott, P.A.; Sibley, P.K.; Somers, W.M.; Lilly, M.R.; Gordon, A.M. A Review of Water Level Fluctuations on Aquatic Biota with an Emphasis on Fishes in Ice-Covered Lakes. J. Am. Water Resour. Assoc. 2008, 44, 343-359. [CrossRef]

4. Wantzen, K.M.; Junk, W.J.; Rothhaupt, K.O. An extension of the floodpulse concept (FPC) for lakes. Hydrobiologia 2008, 613, 151-170. [CrossRef]

5. Aroviita, J.; Hämäläinen, $\mathrm{H}$. The impact of water-level regulation on littoral macroinvertebrate assemblages in boreal lakes. Hydrobiologia 2008, 613, 45-56. [CrossRef]

6. Evtimova, V.V.; Donohue, I. Water-level fluctuations regulate the structure and functioning of natural lakes. Freshwater Biol. 2016, 61, 251-264. [CrossRef]

7. Cui, B.; Tang, N.; Zhao, X.; Bai, J. A management-oriented valuation method to determine ecological water requirement for wetlands in the Yellow River Delta of China. J. Nat. Conserv. 2009, 17, 129-141. [CrossRef]

8. Cui, B.; Hua, Y.; Wang, C.; Liao, X.; Tan, X.; Tao, W. Estimation of ecological water requirements based on habitat response to water level in Huanghe River Delta, China. Chin. Geogr. Sci. 2010, 20, 318-329. [CrossRef] 
9. Becht, R.; Harper, D.M. Towards an understanding of human impact upon the hydrology of lake Naivasha, Kenya. In Lake Naivasha, Kenya; Springer: Dordrecht, The Netherlands, 2002; pp. 1-11.

10. Legesse, D.; Vallet-Coulomb, C.; Gasse, F. Analysis of the hydrological response of a tropical terminal lake, Lake Abiyata (Main Ethiopian Rift Valley) to changes in climate and human activities. Hydrol. Process. 2004, 18, 487-504. [CrossRef]

11. Kummu, M.; Tes, S.; Yin, S.; Adamson, P.; Józsa, J.; Koponen, J.; Richey, J.; Sarkkula, J. Water balance analysis for the Tonle Sap Lake-floodplain system. Hydrol. Process. 2014, 28, 1722-1733. [CrossRef]

12. Benson, L.V.; Paillet, F.L. The use of total lake-surface area as an indicator of climatic change: Examples from the Lahontan Basin. Quat. Res. 1989, 32, 262-275. [CrossRef]

13. Browne, R.A. Lakes as islands: Biogeographic distribution, turnover rates, and species composition in the lakes of central New York. J. Biogeogr. 1981, 8, 75-83. [CrossRef]

14. Shang, S.H. Lake surface area method to define minimum ecological lake level from level-area-storage curves. J. Arid Land 2013, 5, 133-142. [CrossRef]

15. Gippel, C.J.; Stewardson, M.J. Use of wetted perimeter in defining minimum environmental flows. River Regul. 1998, 14, 53-67. [CrossRef]

16. Krstolic, J.L.; Hayes, D.C.; Ruhl, P.H. Physical Habitat Classification and Instream Flow Modeling to Determine Habitat Availability during Low-Flow Periods, North Fork Shenandoah River, Virginia. In U.S. Geological Survey Scientific Investigations Report; USGS: Reston, VA, USA, 2006; Volume 5025, p. 63.

17. Leira, M.; Cantonati, M. Effects of water-level fluctuations on lakes: An annotated bibliography. Hydrobiologia 2008, 6, 171-184. [CrossRef]

18. Poff, N.L.; Zimmerman, J.K. Basic principles and ecological consequences of altered flow regimes for aquatic biodiversity. Environ. Manag. 2002, 30, 492-507.

19. Poff, N.L.; Zimmerman, J.K. Ecological responses to altered flow regimes: A literature review to inform the science and management of environmental flows. Freshwater Biol. 2010, 55, 194-205. [CrossRef]

20. Haxton, T.J.; Findlay, C.S. Meta-analysis of the impacts of water management on aquatic communities. Can. J. Fish Aquat. Sci. 2008, 65, 437-447. [CrossRef]

21. Gafny, S.; Gasith, A.; Goren, M. Effect of water level fluctuation on shore spawning of Mirogrex terraesanctae (Steinitz), (Cyprinidae) in Lake Kinneret, Israel. J. Fish Biol. 1992, 41, 863-871. [CrossRef]

22. Coops, H.; van der Velde, G. Impact of hydrodynamic changes on the zonation of helophytes. Neth. J. Aquat. Ecol. 1996, 30, 165-176. [CrossRef]

23. Fischer, P.; Öhl, U. Effects of water-level fluctuations on the littoral benthic fish community in lakes: A mesocosm experiment. Behav. Ecol. 2005, 16, 741-746. [CrossRef]

24. Cook, C.D.K. Aquatic Plant Book; SPB Academic Publishing: The Hague, The Netherlands, 1990.

25. Armstrong, W.; Brandle, R.; Jackson, M.B. Mechanisms of flood tolerance in plants. Acta Bot. Neerl. 1994, 43, 307-358. [CrossRef]

26. Keddy, P.A. Wetland Ecology: Principles and Conservation; Cambridge University Press: Cambridge, UK, 2010.

27. Van der Valk, A.G.; Welling, C.H. Diversity and pattern in plant communities. In The Development of Zonation in Freshwater Wetlands: An Experimental Approach; During, J.H., Werger, M.J.A., Willems, H.J., Eds.; SPB Academic Publishing: The Hague, The Netherlands, 1988; p. 14.

28. Middelboe, A.L.; Markager, S. Depth limits and minimum light requirements of freshwater macrophytes. Freshwater Biol. 1997, 37, 553-568. [CrossRef]

29. Kolada, A.; Hellsten, S.; Sondergaard, M.; Mjelde, M.; Dudley, B.; Van Geest, G.; Goldsmith, B.; Davidson, T.; Bennion, H.; Noges, P.; et al. Deliverable D3.2-3: Report on the Most Suitable Lake Macrophyte Based Assessment Methods for Impacts of Eutrophication and Water Level Fluctuations; WISER, Institute of Environmental Protection (IEP): Warsaw, Poland, 2011; Available online: http://www.wiser.eu/results/deliverables/.2011 (accessed on 26 January 2018).

30. Hudon, C. Impact of water level fluctuations on St. Lawrence River aquatic vegetation. Can. J. Fish Aquat. Sci. 1997, 54, 2853-2865. [CrossRef]

31. Hill, N.M.; Keddy, P.A.; Wisheu, I.C. A hydrological model for predicting the effects of dams on the shoreline vegetation of lakes and reservoirs. Environ. Manag. 1998, 22, 723-736. [CrossRef]

32. Yamamoto, T.; Kohmatsu, Y.; Yuma, M. Effects of summer drawdown on cyprinid fish larvae in Lake Biwa, Japan. Limnology 2006, 7, 75-82. [CrossRef] 
33. De Nie, H.W.; European Inland Fisheries Advisory Commission. The Decrease in Aquatic Vegetation in Europe and Its Consequences for Fish Populations; Fisheries Department of the Netherlands Ministry of Agriculture and Fisheries: The Hague, The Netherlands, 1987.

34. Savino, J.F.; Stein, R.A. Behavioural interactions between fish predators and their prey: Effects of plant density. Anim. Behav. 1989, 37,311-321. [CrossRef]

35. Kahl, U.; Hülsmann, S.; Radke, R.J.; Benndorf, J. The impact of water level fluctuations on the year class strength of roach: Implications for fish stock management. Limnologica 2008, 38, 258-268. [CrossRef]

36. Stefanidis, K.; Papastergiadou, E. Relationships between lake morphometry, water quality, and aquatic macrophytes, in greek lakes. Fresen. Environ. Bull. 2012, 21, 3018-3026.

37. Doulgeris, C.; Papadimos, D.; Katsavouni, S.; Argyroudi, A. Investigation of the Spatial Distribution of Water Depth and Quality of Lakes Zazari, Cheimaditida, Petron and Vegoritida (D.A1.3); Greek Biotope/Wetland Centre (EKBY): Thermi, Greece, 2017.

38. Shang, S.H. A multiple criteria decision-making approach to estimate minimum environmental flows based on wetted perimeter. River Res. Appl. 2008, 24, 54-67. [CrossRef]

39. CEN. Water Quality—Guidance Standard for the Surveying of Macrophytes in Lakes; I.S. EN 15460: 2007; European Committee for Standardization (CEN): Brussels, Belgium, 2007.

40. CEN. Water Quality-Sampling of Macrophyte Communities in Water Bodies; XP T90-328: 2010; European Committee for Standardization (CEN): Brussels, Belgium, 2010.

41. CEN. Guidance Standard for the Surveying of Aquatic Macrophytes in Lakes; EN 14184; Rep. CEN/TC 230/WG2/TG3:N55; European Committee for Standardization (CEN): Brussels, Belgium, 2003.

42. Kolada, A.; Hellsten, S.; Kanninen, A.; Søndergaard, M.; Dudley, B.; Nõges, P.; Ott, I.; Ecke, F.; Mjedle, M.; Bertrin, V.; et al. Deliverable D3.2-1: Overview and Comparison of Macrophyte Survey Methods Used in European Countries and a Proposal of Harmonized Common Sampling Protocol to Be Used for WISER Uncertainty Exercise Including a Relevant Common Species List; WISER, Institute of Environmental Protection (IEP): Warsaw, Poland, 2009.

43. Jensen, S. An objective method for sampling the macrophyte vegetation in lakes. Vegetatio 1977, 33, $107-118$. [CrossRef]

44. Janauer, G.A. Guidance on the Assessment of Aquatic Macrophytes in Lakes Under the Conditions of the Monitoring for the Water Framework Directive/EU; Monograph; University of Vienna: Vienna, Austria, 2002.

45. Palmer, M.A.; Bell, S.L.; Butterfield, I.A. A botanical classification of standing waters in Britain: Application for conservation and monitoring. Aquat. Conserv. 1992, 2, 125-143. [CrossRef]

46. Fasset, N.C. A Manual of Aquatic Plants; The University of Wisconsin Press: Madison, WI, USA, 1957.

47. Ascherson, P.; Graebner, P. Potamogetonaceae. In Das Pflanzenreich, Regni Vegetabilis Conspectus; Verlag von J. Cramer, H.R. Engelmann: Weinheim, Germany, 1959; p. 81.

48. Wood, R.D.; Imahori, K. Iconograph of the Characeae; Verlag von J. Cramer: Weinheim, Germany, 1964.

49. Wood, R.D.; Imahori, K. Monograph of the Characeae; Verlag von J. Cramer: Weinheim, Germany, 1965.

50. Tutin, T.G.; Heywood, V.H.; Burges, N.A.; Moore, D.M.; Valentine, D.H.; Walters, S.M.; Webb, D.A. Flora Europaea; Cambridge University Press: Cambridge, UK, 1968; Volume 2-4.

51. Tutin, T.G.; Burges, N.A.; Charter, A.O.; Edmondson, J.R.; Heywood, V.H.; Moore, D.M.; Valentine, D.H.; Walters, S.M.; Webb, D.A. Flora Europaea, 2nd. ed.; Cambridge University Press: Cambridge, UK, 1993.

52. Correll, D.S.; Correll, H.B. Correll, Aquatic and Wetland Plants of Southwestern United States; Environmental Protection Agency: Washington, DC, USA, 1972; Volume 1.

53. Casper, S.J.; Krausch, H.D. Pteridophyta und Anthophyta 1. In Subwasserflora von Mitteleuropa; Gustav Fischer Verlag: Stuttgart, Germany, 1980; Volume 23.

54. Casper, S.J.; Krausch, H.D. Pteridophyta und Anthophyta 2. In Subwasserflora von Mitteleuropa; Gustav Fischer Verlag: Stuttgart, Germany, 1981; Volume 24.

55. Krause, W. Charales (Charophyceae). In Subwasserflora von Mitteleuropa Bd 18; Spektrum Akademischer Verlag: Heidelberg, Germany, 1997.

56. Strid, A.; Tan, K. Flora Hellenica; Koeltz Scientific Books: Königstein, Germany, 1997; Volume 1.

57. Strid, A.; Tan, K. Flora Hellenica; Koeltz Scientific Books: Ruggell, Liechtenstein, 2002; Volume 2.

58. Crow, G.E.; Hellquist, C.B. Crow, Aquatic and Wetland Plants of Northeastern North America; The University of Wisconsin Press: Madison, WI, USA, 2000.

59. Pedrotti, C.C. Flora Dei Muschi d'6 Italia; Parte I; Delfino, A., Ed.; Libro Universitario: Roma, Italy, 2001. 
60. Pedrotti, C.C. Flora Dei Muschi d'6 Italia; Parte II; Delfino, A., Ed.; Libro Universitario: Roma, Italy, 2006.

61. Schumacker, R.; Vana, J. Identification Keys to the Liverworts and Hornworts of Europe and Macaronesia; Ed. Sorus: Poznan, Poland, 2005.

62. Froese, R.; Pauly, D. (Eds.) FishBase: World Wide Web Electronic Publication. Available online: www. fishbase.org (accessed on 10 February 2018).

63. Hartog, C.; Segal, S. A new classification of the water-plant communities. Acta Bot. Neerl. 1964, 13, 367-393. [CrossRef]

64. Economidis, P.S.; Dimitriou, E.; Pagoni, R.; Michaloudi, E.; Natsis, L. Introduced and translocated fish species in the inland waters of Greece. Fish. Manag. Ecol. 2000, 7, 239-250. [CrossRef]

65. CEN. Water Quality—Sampling of Fish with Multimesh Gillnets; I.S. EN 14757: 2005; European Committee for Standardization (CEN): Brussels, Belgium, 2005.

66. Kiernan, J.D.; Moyle, P.B.; Crain, P.K. Restoring native fish assemblages to a regulated California stream using the natural flow regime concept. Ecol. Appl. 2012, 22, 1472-1482. [CrossRef] [PubMed]

Publisher's Note: MDPI stays neutral with regard to jurisdictional claims in published maps and institutional affiliations.

(C) 2020 by the authors. Licensee MDPI, Basel, Switzerland. This article is an open access article distributed under the terms and conditions of the Creative Commons Attribution (CC BY) license (http://creativecommons.org/licenses/by/4.0/). 